\title{
Rendőrtisztképzés az Európai Unió néhány országában, jó gyakorlatok
}

\author{
FÓRIZS Sándor ${ }^{1 \oplus}-$ MÉSZÁROS Bence $^{2 \oplus}$
}

\begin{abstract}
50 éve vette kezdetét a felsőoktatási keretek között zajló rendőrtisztképzés hazánkban.AzótaafelkészítésjelentősfejlődésenmentkeresztülaRendőrtiszti Főiskola jogutódján, a Nemzeti Közszolgálati Egyetem Rendészettudományi Karán. A különböző mesterképzési szakok (többek között rendészeti vezető, illetve kriminalisztika mesterképzés, civilek számára biztonsági szervező mesterképzés) alapításától a Rendészettudományi Doktori Iskola akkreditálásáig sok elöremutató változás történt a képzésfejlesztés területén. A szerzők a jeles évforduló alkalmából megvizsgálják az Egyesült Királyság és az Európai Unió néhány tagországa hasonló jellegú felkészítéseinek sajátosságait, bemutatják az azokban érvényesülö, esetlegesen hazánkban is felhasználható jó gyakorlatokat. Az olvasó a tanulmányból megismerheti a rendőrtisztképzést folytató intézményekbe történő bekerülés nemzeti sajátosságait, a bachelor-és masterképzések szerkezeti, tartalmi megoldásait és egyes kapcsolódó PhD-kurzusokat. A tanulmány bemutatja néhány, rendőrtisztek képzését végző külföldi felsőoktatási intézmény szervezeti felépítését, számba veszi azok egyéb lehetséges feladatait, mint például a rendőrségi továbbképzésben vagy a magánbiztonsági felkészítésben részvétel. A téma iránt érdeklődő megismerhet olyan megoldásokat, amelyekben a rendőri felkészítés polgári felsőoktatási intézményekben történik. A szerzők által elvégzett kitekintés értékeli a rendőrtisztképzés irányításának lehetséges szakmai változatait, az abban részt vevő hallgatók jogi helyzetét, az elhelyezésük és felkészítésük, valamint a beosztásba helyezésük fontosabb kérdéseit.
\end{abstract}

Kulcsszavak: rendőrtisztképzés külföldön, moduláris felkészítés, felvételi követelmények, rendör egyetem, rendör főiskola, nemzetközi jó gyakorlatok

\footnotetext{
Dr. Fórizs Sándor ny. rendőr dandártábornok, ny. egyetemi tanár, Nemzeti Közszolgálati Egyetem Rendészettudományi Kar.

Sándor Fórizs, PhD, ret. Police Brigadier-General, University of Public Service, Faculty of Law Enforcement, ret. Professor.

E-mail: drforizs@gmail.com

2 Dr. Mészáros Bence r. ezredes, Nemzeti Közszolgálati Egyetem Rendészettudományi Kar, Nyomozáselméleti Tanszék, nemzetközi dékánhelyettes, egyetemi docens, tanszékvezető.

Bence Mészáros, PhD, Police Colonel, University of Public Service, Faculty of Law Enforcement, Department of Investigation Theory, Associate Professor, Head of Department.

E-mail: meszaros.bence@uni-nke.hu
} 


\section{Bevezetés}

Az alábbiakban az Európai Unió hét tagállamának (Németország, Ausztria, Finnország, Franciaország, Hollandia, Románia, Szlovákia), illetve az Egyesült Királyságnak azokat a képzéseit és felsőoktatási intézményeit mutatjuk be, amelyek rendőri területen akkreditált képzéseket folytatnak. Tesszük mindezt azért, hogy hazánk rendészeti felsőoktatását kontextusba helyezzük, és legyen összehasonlítási alapunk a jelenlegi helyzetünk értékeléséhez, illetve a jövőbeli fejlődési irányok meghatározásához.

\section{A német rendőr felsőoktatás}

A német rendőrségek szervezeti rendszere leképezi a Német Szövetségi Köztársaság államszerkezetének felépítését. Az ország közigazgatásilag 16 tartományra és a szövetségi kormányra, illetve annak szerveire tagozódik. Az alaptörvény szerint a rendőrség tartományi ügy, ezért a tartományok saját rendőrséget tartanak fenn saját belügyminiszterük alárendeltségében. Mivel egy ilyen hatalmas ország a maga 82 millió lakosával központi rendőri szervek nélkül nem képes múködni, a szövetségi kormány (német szóhasználattal a Bund, azaz a Szövetség) is rendelkezik kettő, a parlament, a Bundestag pedig egy rendőrséggel. ${ }^{3} \mathrm{Az}$ összesen 19 különálló rendőrség tagjai felsőoktatási, főiskolai és egyetemi felkészítése 18 tanintézetben történik. A rendőrtiszti munkakör betöltése főiskolai végzettséghez kötött. A tanintézet záróvizsgája egyben tiszti vizsga is, a végzett hallgató a nálunk funkcionáló hadnagyi rendfokozatnak megfelelő Kommissar rendfokozattal egycsillagos tisztként kezdi pályafutását. A német rendszerben hat tiszti rendfokozat található (egyes tartományokban csak öt) 1-5 ezüstcsillaggal jelölve a váll-lapon, és a beosztási táblázatban ezek a tisztek az A9 - A13 jelölésű munkaköröket tölthetik be. ${ }^{4}$ A lábjegyzetben jelöltnél magasabb rendfokozatot és az ahhoz kapcsolódó magasabb beosztást csak az érhet el, tölthet be, aki elvégezte a rendőr egyetem (helyileg Münster) kétéves képzését. A tanulmányait itt befejezett tiszt felteheti vállára az első aranycsillagot (rendőrtanácsos), és később a további három főtiszti rendfokozatot is megszerezheti, igen kedvező esetben. ${ }^{5}$ Ezt követik a tábornoki rendfokozatok. A fötisztek, tehát az aranycsillagosok, a teljes rendőri állomány 2-3\%-át képezik, azaz a magyar viszonylathoz képest rendkívül kevesen vannak, és igen magas az illetményük, az általános elismertségük.

Lásd Fórizs Sándor: Gondolatok Németország rendőrségi rendszeréről. Belügyi Szemle, 63. (2015), 10. 47-64.

Polizeikommissar (PK) 1 csillag A9, Polizeioberkommissar (POK) 2 csillag A10, Polizeihauptkommissar (PHK) 3 csillag A11, Polizeihauptkommissar (PHK) 3 csillag A12, Polizeihauptkommissar 4 csillag A12 (nem minden tartományban), Erster Polizeihauptkommissar (EPHK) 5 csillag A13. A megegyező csillagszám esetében a magasabb rendfokozatot pótlék honorálja.

5 Főtiszti rendfokozatok: Polizeirat, (PR) 1 csillag A13, Polizeioberrat (POR) 2 csillag A14, Polizeidirektor (PD) 3 csillag A15, Leitender Polizeidirektor (LPD) 4 csillag A16/B2/B3. (rendőrtanácsos, rendőr fôtanácsos, rendőr igazgató, vezető rendőr igazgató). 


\section{A német tanintézetek múködésének szervezeti és jogi háttere}

A 18 tanintézet között jelentős szervezeti és anyagi különbségek találhatók. A külső szemlélő számára úgy tủnik, valamennyi tartomány rendőrsége, függetlenül létszámuktól és anyagi lehetőségüktől, törekszik önálló tisztképzés fenntartására. Így a 3000 vagy 30 ezer rendőrt foglalkoztatók is saját intézményt múködtetnek, amelyek lehetőségei azért lényegesen eltérnek egymástól. Többször felmerült például Brandenburg és Berlin oktatásának egy keretben történő összefogása, de eddig az érintettek elzárkóztak ettôl. Az iskolák múködését tartományi törvények, belügyminiszteri rendeletek szabályozzák. 2009-2010 körül bachelorszakokat alapítottak, és áttértek a bolognai típusú felkészítésre. Már az intézmények megnevezése is különböző, főiskola, szakfőiskola, rendôr akadémia a leggyakoribb megoldás. Szervezetileg az alábbi változatokat találjuk:

- Önálló tanintézet külön bázison, saját speciális felépítéssel. Akkreditációja is önállóan zajlott. Ilyen a Rendőrség Német Főiskolája (tulajdonképpen rendőr egyetem) Münsterben.

- Polgári főiskolán belül rendőri kar múködtetése, vezetője a dékán, egy rendőrtiszt. Ilyen Berlin, ahol a karon belül még egy magánbiztonsági szakot is fenntartanak.

- Nagyobb rendőri oktatási intézmény egyik részlege a tulajdonképpeni főiskolai képzést végző kvázi „kar”, amely egy polgári közigazgatási főiskola kihelyezett szakiránya. Ilyen a szövetségi rendőrség részére felkészítést végző Rendőr Akadémia Lübeckben, a Szövetségi Közigazgatási Főiskola (Brühl) kihelyezett képzése „Szövetségi rendőrségi szakirány” megnevezéssel. A kar dékánja egyben az egész nagyobb szervezet vezetője is.

- Önálló elhelyezésben, saját speciális szervezettel múködő, de a tartományi közigazgatási főiskolával akkreditálási szimbiózisban lévő intézmény. Ez a leggyakoribb megoldás. Vezetője rektor, igazgató, iskola vezető címet visel és például egy kétcsillagos rendőr tábornok.

Németországban 30 közigazgatási főiskola múködik, így nem okozott gondot partnerintézményt találni. Az iskolákat a szövetségi állam vagy a tartományi kormányok finanszírozzák, Münster költségvetését a tartományok és a központi kormány, a Lübeck és Wiesbaden kiadásait szintén a szövetség, a „Bund” fedezi. A rendőrképzés irányítás szempontjából a belügyminisztériumokhoz lett bekötve, természetesen az adott felsőoktatási törvények követelményeit ez nem befolyásolja. Mindenesetre az irányítási rendszer a magyarországinál nagyobb mozgásteret biztosít a rendőrségnek a hallgatók felvétele és a szakmai feladatok teljesítése terén.

Különösen a kisebb tartományok esetében, feltételezésem szerint költségtakarékosság okából, a főiskolák nagy, komplex intézmények. Ide lett telepítve a tartomány rendőrtiszthelyettes-képzése, a rendőrség továbbképzése, a teljes felvételi ügyintézés, a tartományi rendőrségi múzeum és könyvtár, a rendőrségi tudományos és kutató- 
intézetek. Ennek megfelelően a tanintézet vezetője több helyettessel is rendelkezik, akik az eltérő feladatokat - tiszthelyettesképzés, főiskolai oktatás, továbbképzés, tudományos és nemzetközi tennivalók, belső igazgatás - külön-külön ellátják. A rendszer előnye az erők és eszközök összefogott alkalmazási lehetősége. A tanári-kiképző gárda több szinten is tevékenykedhet. A nagyobb tartományokban a jelentősebb létszámú hallgatói állomány ilyen megoldásokat nem tesz lehetővé, ott „tisztán” főiskolai képzés folyik az intézmény falain belül, esetleg több városba kihelyezett campusokon.

$\mathrm{Az}$ intézmények rendelkeznek minden, a modern felsőoktatási követelmények szerinti szervezettel, szenátussal, hallgatói önkormányzattal, tanácsadó testülettel, professzorok tanácsával stb. Legalább két olyan iskola is múködik (Berlin, Brandenburg), ahol a hallgatóknak nem biztosítanak diákszállást, arról a tanulmányokban részt vevőknek maguknak szükséges gondoskodni az intézmény anyagi támogatása mellett. Az egyik indoklás szerint ez elősegíti a polgárbarát szemlélet erősödését, és csökkenti a katonai jellegű drillt. A kibocsátó ünnepségekről teljesen hiányzik a kardos-zászlós-alakzatos megoldás.

\section{Felvételi a föiskolákra}

A rendőr főiskolai képzésre jelentkezés feltételei csekély mértékben tartományonként eltérőek lehetnek. Alapvetően érettségit követően lehet pályázni. Ez alól kis számban sajátos megoldásokkal kivételt tesz néhány tanintézet. Szempontok:

- Egyes iskolák előírnak bizonyos szintű hozott osztályzatokat, például az érettségivel jelentkezőknek a hatpontos (hatos a legrosszabb osztályzat) értékelési rendszerben legalább 2,5-es eredménnyel szükséges rendelkezniük, vagy angol nyelvtudás valamilyen szintjével.

- A lehetséges életkor 16-45 év (más változatban 17-47) között ingadozik.

- Pszichológiai teszten történő megfelelés.

- Büntetlen előélet.

- Sportfelmérés teljesítése. A pályázó nem lehet túlsúlyos, vagy kisebb súlyú, a testtömegindexe, (body mass index - BMI) legyen 18 és 27, 5 között.

- Bemutatkozó beszélgetésen történő pozitív megítélés.

- Rendőrorvosi egészségügyi megfelelés.

- Csoportos munkabeszélgetésen megfelelés.

- „B” kategóriás járművezetői engedély a jelentkezés idején, vagy megszerzése a képzés egyik előírt szakaszára.

- Az elvárt testmagasság tartományonként váltakozva 155-165cm között ingadozik.

- Úszástudás, esetleg bronz úszójelvény megléte.

- A tetoválások, piercing, hegtetoválás (branding), vonatkozásában is eltérőek a követelmények. Általában a nyári öltözet ruhától fedetlen részein nem lehet 
ilyen díszítés, a tetoválások nem lehetnek szexuális jellegűek, nem irányulhatnak a nők, a kisebbségek, a másság ellen; nem hirdethetnek szélsőséges nézeteket és erőszakot.

- A német állampolgárság megkövetelése sem egységes. Az eltérések a csak német állampolgár, az uniós és EWR-állampolgár, vagy harmadik ország polgára is lehet, változatokban szerepelnek. Az utóbbiak esetében a középiskolai végzettséget igazoló okmányokat honosíttatni szükséges. Előirhatnak néhány év németországi lakhatást, illetve időbeni korlátozást nem tartalmazó tartózkodási engedély meglétét. A legnagyobb akadályt külföldiek esetében a német nyelv írásban és szóban történő megbízható alkalmazása jelenti. A bejutott szerencsések számára az oktatás állampolgárságuktól függetlenül ingyenes, és a végzést követően a beiskolázó rendőrség az érintettnek tiszti beosztást biztosít.

A jelentkezések többnyire online történnek, és a rendőrség illetékes, személyzeti szervezetéhez kell azokat beküldeni. A felvételi eljárások egy-három nap között ingadoznak, esetleg a napokat eltolják egymástól. A felvételihez szükséges utazás költségeit megtérítik, szükség esetén szállást biztosítanak. Minden mozzanatot a toborzástól a beiskolázásig, egyes esetekben, a rendőrség rendez, a tanintézetek a felvettek névjegyzékét kapják meg. Más tartományokban a tanintézet is részt vesz a felvételi eljárásban. Törekednek bizonyos speciális kategóriák, például török nemzetiségúek felvételére. A felvételi eljárásra történő felkészülést az interneten mintatesztek (német nyelvtan, helyesírás, általános társadalmi ismeretek stb.) közzétételével és a fizikai felmérés videón történő bemutatásával, az ügyintézők elérhetőségének megadásával segítik.

A felvett hallgatók „visszahívható” állománykategóriába kerülnek, a végzést követően általában két évig próbaidősek. A tanulmányi ösztöndíj 1100-1300 euró között mozog, esetleg családi pótlék egészíti ki. Németországban nagy jelentősége van az ingyenes orvosi ellátásnak, amelyet a tartományok nem egységesen biztosítanak, de a szövetség központilag finanszíroz. A hivatásos tiszthelyettesek nappali főiskolai tanulmányaik idején illetményben részesülnek.

\section{A föiskolai képzés}

A teljes német rendőr felsőoktatás „Bologna-kompatibilis”, egyszer vagy ismételten akkreditált. A rendőri szakok, szakirányok megnevezése nem egységes, de belső tartalmukat nézve szinte homogén. Az elnevezés egyik változata „Rendőr végrehajtó szolgálat”, „Polizeivollzugdienst”, (Police Service). A diplomák megnevezése sem egységes, „Bachelor of Arts”, esetleg „Diplomás igazgatási szakértő, rendőrség”, „Diplom-Verwaltungswirt Polizei (FH)”. Az országban nem található levelező főiskolai tisztképzés, a jelenlét a foglalkozásokon kötelező. Önálló rendőri szak három változatban múködik, közrendvédelmi, bűnügyi, vízi rendőrségi (az utóbbi csak két tarto- 
mányban). A beiskolázás általában őszi kezdéssel évente egy alkalommal, egyes intézetekben évente kétszer is keresztféléves rendszerben zajlik. A vízi rendőrségi képzést Hamburgban Európa egyik legnagyobb kikötőjének fenntartása, működtetése indokolja. Külön toboroznak a tanulmányokra, már az induláskor elválasztják a másik szaktól a felkészítés speciális feladatrendszere és tananyaga miatt. Az itt végzetteket az Északi- és a Keleti-tengeren is alkalmazzák. A felvételi eljárásban előnyt élveznek a tengerészeti felkészültséggel, előélettel rendelkezők (kapitányi, elsőtiszti vizsga, gépészeti-halászati ismeretek). A kezdő rendfokozat eggyel magasabb a szárazföldi alkalmazásnál, a tanulmányok alatt a hallgatók kiemelt ösztöndíjban részesülnek. Egyes iskolákon már az oktatás indításakor szétválasztják a hallgatókat bűnügyi és közbiztonsági területre (30 és 70\%). Más intézetek két-három modult tartanak fenn az eltérő tananyag számára, és a harmadik évben specializálódik az állomány. A magyarországi nagyszámú szakirányra és nappali-levelező bontásra a német rendszerben nincs példa, ami szintén nagyobb erő-összpontosítást tesz lehetővé.

A hatszemeszteres, heti 40 kontaktórás oktatás moduljellegú, 14-20 modulra oszlik. Szinte mindenütt legalább két modul, két teljes szemeszter, szakmai gyakorlat a kinti rendőri szerveknél, ez a megoldás lényegesen erősebb a magyarországinál. A 180 kreditből 120 az elméleti és 60 a gyakorlati felkészítést szolgálja. Az oktatás a bachelormunka elkészítésével (általában minimum 40 oldal), és megvédésével, és egy ehhez kapcsolódó szóbeli záróvizsgával fejeződik be. Valamennyi modul vizsgával, esetleg gyakorlati jeggyel zár. Az értékelés pontrendszerben, 1-15 pont, ahol a minimum elérendő pontszám öt, vagy 1-6 skálán osztályzással történik. A hároméves képzést lezáró végértékelés $80 \%$-ban a modulvizsgák és 20\%-ban a szakdolgozat, záróvizsga átlagából áll össze. A hallgató kérheti, hogy a szabadon válaszható modulok értékelését a végosztályzatba beszámítsák, vagy esetleg ne vegyék figyelembe. A modulok anyagának feldolgozását azonnal követi a modulvizsga, esetleg két-három nap felkészülést biztosítanak. Ennek megfelelően hiányzik a hosszú vizsgaidőszak. Mindez jelentős óraszámot szabadít fel a szakmai felkészítéshez. Brandenburgban 4500 kontaktóra a három év óraszáma.

Az oktatott tananyagban a magyarországitól jelentős eltérés nincs. 120 kreditpont esik a szakmai elméleti tantárgyakra, mint büntetőjog, rendőrségi jog, közszolgálati jog, állam- és alkotmányjog, közigazgatási jog, polgári jog, közlekedési jog. Ugyanakkor más tantárgyak, úgymint a bevetéselmélet, közlekedési elmélet, kriminalisztika, kriminológia, pszichológia, rendőrség története, etika, rendészettudomány stb. 60 kreditponttal szerepelnek, hasonlóan más gyakorlati tantárgyhoz/képzéshez, gondolva itt a lövészetre, intézkedéstaktikára, jármúvezetési gyakorlatra, rendőri informatikára, kommunikációs gyakorlatra, elsősegélynyújtásra, úszásra, mentésre, vagy a szakmai gyakorlatra.

Sok tanintézet jelentős számban engedi be a nappali felkészítésbe a munkájukban jól szerepelt tiszthelyettes állományt, Bajorországban a hallgatók 75\%-a tiszthelyettes. Ezekben az esetekben a tiszthelyettesek és a közvetlenül a középiskolákból érkezők együttes felkészítése csak a harmadik szemeszterben kezdődik. A polgári 
életből érkezőknek egy szemeszter elméleti és egy szemeszter gyakorlati felkészítés folyik az első évben. A tiszthelyetteseknek kevesebb a szakmai gyakorlata.

Mecklenburg-Vorpommern tartomány iskolájában (Güstrow) a hatszemeszteres, hároméves képzés mellett tiszthelyettesek részére 18 hónapos rövidített BA-felkészítés is folyik. A számukra adományozott diploma megnevezése „Bachelor of Arts - Polizeivollzugsdienst” („Bachelor of Arts, Rendőr Végrehajtó Szolgálat”). A megelőző tiszthelyettesi szolgálatot és az ahhoz kapcsolódó szakmai tapasztalatokat a képzés kredit- és teljesítménypontokkal ismeri el.

A 18 hónapos képzésre jelentkezés feltételei:

- legalább hároméves tiszthelyettes-szolgálat a próbaidő lejártát (véglegesítést) követően, a próbaidő a tiszthelyettesképzés befejezésével kezdődik;

- az utolsó előírt minősítés alkalmával legalább „jó” minősítést kaptak;

- legalább két szolgálati helyen hosszabb ideig szolgálatot teljesítettek;

- a főiskolai tanulmányokat lehetővé tevő középiskolai végzettséggel rendelkeznek.

Ugyanitt egy harmadik típusú BA-tanulmány is létezik 6 hónapos időtartamban azon tiszthelyettesek részére, akik korábban elvégeztek egy „Előmeneteli Képzés Különleges Alkalmazásra”, „Aufstiegsausbildung für eine besondere Verwendung” megnevezésű felkészítést legalább „megnyugtató” „2”-es eredménnyel, és középiskolai érettségivel rendelkeznek. A végzettek részére a főiskola a „Diplomás igazgatási szakértő, rendőrség”, „Diplom-Verwaltungswirt Polizei (FH)” megnevezésú diplomát állítja ki, amely valamennyi tiszti (nem főtiszti) beosztás betöltésére és további egyetemi tanulmányok folytatására jogosít.

A mecklenburgi tanintézetben külön 9 hónapos tanfolyam jellegü képzés is folyik tiszthelyettesek részére, amely nem biztosít felsőoktatási diplomát. A végzettek a tartományban az A11-es illetményfokozatú tiszti munkaköröket (kezdő beosztások) betölthetik, ennél magasabbakat nem. Ezzel a lehetőséggel bővítik az idősebb tiszthelyettesi állomány mozgásterét.

Schleswig-Holsteinben (Altenholz) a tiszthelyettes-állomány részére szintén háromszemeszteres BA-képzést akkreditáltak. Az itteni az országban a másik főiskola önálló szakon folytatott vízi rendőri képzéssel. A tartomány földrajzi elhelyezkedéséből következik, hogy a szakon végzettek az Északi- és Keleti-tengeren fognak dolgozni.

Alsó-Szászország és Saarland tartományokban az élsportolóknak lehetőségük nyílik öt évig folytatni a BA-tanulmányokat és eközben kvalifikáltatni magukat a sport területén. A dokumentum a könnyű atlétika, úszás, judo sportágakat említi. A lehetőség a „Bundeskader A, B, C” (szövetségi besorolású személy) besorolású nemzetközi, nemzeti élsportolók, illetve utánpótlás (címvárományos) személyekre vonatkozik.

Sajátosság Alsó-Szászország tartományban, hogy a 11 osztályos képzést befejezők részére (szakképzés), akik a tartomány felsőoktatási törvénye alapján nem jogosultak 
felsőfokú tanulmányokra, szintén tartanak felvételi eljárást a rendőrséghez. Az ezen sikeresen szereplőknek a főiskolán egyéves kurzust indítanak, amelynek eredményes befejezését követően újabb felvételi nélkül kezdhetik meg hároméves rendőrségi tanulmányaikat. A résztvevő nem lehet 31 évesnél idősebb.

Az Erasmus-program mellett a tanrendbe beépített külföldi gyakorlati tanulmányi lehetőséget is szerveznek, például két hét időszakra, különösen azoknál a tartományoknál, amelyek más államokkal is határosak. Idegen nyelvi rendőri szakmai felkészítést kisebb óraszámban (70 kontaktóra) angol, francia, dán, török nyelven végeznek. Berlinben a Gazdasági és Jogi Főiskolán folyik rendőrfelkészítés az 5. „Rendőri és magánbiztonsági karon”. Az iskolában nincs speciális rendőri felkészítésre lehetőség, ezért a gyakorlati foglalkozások jelentős részét a rendőrség készenléti alakulatához és a városi tiszthelyettes iskolához szervezik blokkosított tervezéssel. Ennek megfelelően igen jelentős a külső foglalkozásvezetők aránya, gyakran 50\%. Bírók, ügyvédek, rendőrtisztek, legkülönbözőbb szakemberek szerepelnek a listán, akik szerződés alapján térítés ellenében tartják az órákat, viszont alacsonyabb a főállású oktatók száma. A hallgatók a polgári iskolán látogatásomkor civilben tanultak, és a „kinti” rendőrségi foglalkozásokon viseltek egyenruhát.

Az oktatók foglalkoztatásának egyik formája a rendőri munkahelyekről három évre a tanintézethez történő vezénylés, kiegészítő pótlék fizetése mellett. Egyes oktatási egységeknél, például bűnügyi szakterület, három ilyen munkakör is van, és évente egy személy visszamegy a rendőrséghez, egy pedig érkezik, amolyan szakoktatói feladatok ellátására. Ezen a módon is biztosítják a legfrissebb ismeretek hallgatókhoz kerülését.

A huzamosabb ideig tartó szakmai gyakorlatok esetében a fogadó rendőrszervezetektől tapasztalt mentorokat foglalkoztatnak külön díjazás mellett. Velük felkészítő foglalkozáson pontosítják az elvárásokat.

A Szövetségi Bűnügyi Hivatal (Bundeskriminalamt - BKA) a Szövetségi Közigazgatási Főiskolával kooperálva önálló bűnügyi rendőrségi szakirányt (BA) tart fenn Wiesbadenben, a bűnügyi hivatal központjában, kizárólag bűnügyes tisztek képzése céljából. Hatszemeszteres nappali felkészítés. Az első négy modul Brühlben, majd a további képzés Wiesbadenben zajlik két fő szakaszra osztva, 1-7. modul és 9-12. modul. A 8. és 13. modulok szakmai gyakorlat az ország területén rendőri kötelékeknél.

\section{Szövetségi Rendör Akadémia, Lübeck, Bundespolizeiakademie}

Az akadémia a főiskolák közül annyiban a nagysága mellett legjelentősebbnek tekinthető, hogy a központi, szövetségi rendőrség részére képez tiszteket.

Az intézmény 1950-től folytat rendvédelmi/rendészeti felkészítést. Először a Szövetségi Határőrség (Bundesgrenzschutz) szakfőiskolája volt. A határőrség szövetségi rendőrséggé történt átszervezését követően az új szervezet tisztjelöltjeinek képzése folyt itt. A 2008-as átszervezés után a szövetségi rendőrség kiképző és továbbképző 
intézményei az akadémia szervezetébe kerültek (összesen 7, a tiszthelyettes iskolákkal együtt). Az akadémia elöljáró szerve a Szövetségi Rendőrség elnöksége, állomáshelye Potsdam.

$\mathrm{Az}$ akadémia a szövetségi rendőrség részére folytat tiszthelyettesképzést, BAés MA-felkészítést (utóbbinak az első évét). A továbbképzés területén művelt szakterületek: határrendőrség, vasúti rendőrség, légi biztonsági felkészítés, rendőrségi technika, külföldi alkalmazás, rendőrorvosi szolgálat.

A főiskolai és egyetemi felkészítés az akadémia szervezetén belül zajlik Szövetségi Közigazgatási Főiskola Szövetségi Rendőrségi Szakirány (Fachbereich Bundespolizei der Hochschule des Bundes für öffentliche Verwaltung) megnevezéssel. A Szövetségi Közigazgatási Főiskola (múködési helye Brühl) kihelyezett tagozataként funkcionál a főiskolai szintű felkészítés.

A főiskolai képzés dékánja egyben az akadémia vezetője is, jelenleg egy kétcsillagos rendőr tábornok.

A bachelorfelkészítés hatszemeszteres nappali képzés erős tagoltsággal. Négy hónap alapképzés Lübeckben, egy szemeszter Brühlben, a közigazgatási főiskola többi szakirányával közösen. Ezt követően elmélet és gyakorlat váltakozva. Elmélet 3-4-4-4 hónapos blokkokban, illetve mindig utánuk egy emelkedő szintű szakmai gyakorlat valamilyen végrehajtó szervezetnél 3-2-4 hónapokkal. Azaz szakmai gyakorlat összesen 9 hónap és egy 4 hónapos bevezető alapfelkészítés képezi a gyakorlati oldalt.

A Hamburgi Rendőrség Akadémiája tipikusan olyan intézmény a német rendszerben, ahol egy szervezeten belül egyesítettek minden képzési-kiképzési területet. A tulajdonképpeni rendőri főiskola az akadémia negyedik részlegét képezi. Az itteni 4. szakfőiskolai részlegen végzik a bachelorképzést, a rendőr tisztjelöltek felkészítését. A részleget a dékán irányítja, akit a 20 fő professzor saját köréból két évre választ, és ő egyben az akadémia vezetőjének helyettese is. 18 fő docens és tudományos munkatárs egészíti ki a professzori csoportot. A 4. részleghez tartozik egy vizsgaközpont, amelynek feladata az előírt vizsgák előkészítése.

A brandenburgi főiskolán (Oranienburg) 2020-óta múködik egy akkreditált mesterszak „Kriminalistik” megnevezéssel a bűnügyi rendőrség tagjai szakmai felkészítése céljából.

\section{A Rendörség Német Föiskolája, „Die Deutsche Hochschule der Polizei”, masterfelkészités}

Jelentőségénél fogva külön meg kell említenünk Európa egyik meghatározó, talán legszínvonalasabb, önálló rendőr egyetemét. Itt zajlik a szövetségi köztársaság vezető rendőrtisztjeinek felkészítése. A bolognai típusú akkreditációt megelőzően a képzés neve „Ratslehrgang”, „tanácsosi tanfolyam” volt, mivel ezzel a tanulmánnyal lehetett elérni a rendőrtanácsosi rendfokozatot. Előd tanintézete a Rendőr Vezetési Akadémia 
(Polizei-Führungsakademie) 2005-ben lett akkreditálva egyetemmé, az új típusú képzést 2007-ben kezdték, az egész ország valamennyi rendőrsége főtisztjeinek - rendőrtanácsos rendfokozattól felfelé - felkészítése számára. Állami fenntartású intézmény, amelynek költségvetését a szövetségi kormány és a tartományok együttesen viselik.

\section{A tanulmányok megkezdésének feltételei}

Tanulmányokat kizárólag valamelyik német rendőrség hivatásos állományú tagja folytathat. A felvételi eljárást a küldő szerv folytatja le és végzi a beiskolázást. A 19 rendőrség meghatározott számú hellyel rendelkezik éves elosztásban.

Felvételi feltételek:

- 40 éves korhatár, kivételes esetekben 45 év, amennyiben a jelentkező önhibáján kívül eddig jelentkezni nem tudott, és a tartományi életpálya-rendelet a kivételt megengedi;

- főiskolai végzettség, vagy annak megfelelő képzettségi szint;

- befejezett főiskolai tanulmányok a közigazgatás területén (a német rendszer idesorolja a rendőrtiszti főiskolákat), vagy ennek megfelelő iskolai végzettség és a tiszti pályához szükséges vizsga letétele, ezt követően szolgálati tapasztalatok szerzése a szakmai pályafutás során, a felkészültség bizonyítása, valamint a legjobbak kiválasztására vonatkozó felvételi eljáráson történő megfelelés és a tanulmányok megkezdéséhez elöljárói hozzájárulás szerzése;

- vagy egy tudományos főiskola diplomájával rendelkezés és a tartományi, illetve a szövetségi rendőri szervek legjobbak kiválasztására vonatkozó felvételi eljárásán történő megfelelés és a tanulmányok megkezdéséhez elöljárói hozzájárulás szerzése;

- annak, aki teljesítette a második szintű jogi államvizsgát, vagy polgári főiskolai végzettséget követően a magasabb általános közigazgatási szolgálathoz szükséges államvizsgát letette az egyetem egy külön továbbképzési programot kínál fel.

A tanintézet 400 hallgatóval rendelkezik. A képzés első éve decentralizálva, egyes tartományok tanintézeteiben kihelyezett formában történik. A hallgatók számára egyhónapos bevezető felkészítést tartanak, 16 kötelező és két kötelezően választható modult dolgoznak fel, 7-7 modult az első és második évben, és 4 modult mindkettőben.

A tantárgyak a felső szintű rendészeti képzés szokványos anyagának felelnek meg, de igen magas vezetői feladatok ellátására készítenek fel. A színvonal komolyságát mutatja, milyen feladatok teljesítését várják el a végzettektől.

A végzettektől elvárt követelmények:

- nagyobb rendőrségi szolgálati helyek és kötelékek vezetése;

- rendőrségi bevetések vezetése; 
- különleges feladatok teljesítése a tartományi és szövetségi központi és legfelsőbb szerveknél;

- közremúködés a rendőri állomány kiképzésében és továbbképzésében.

A tanulmányokat különösen erősíti a nappali képzési jelleg. A két kötelezően választható modulon belül 15 + 9 rendkívül komoly, magas, 60-80 kontaktóraszámú öt kredites tématerületet kínálnak fel.

A megszerzett végzettség, a master fokozat, „Master of Arts” (M.A.), németül „Öffentliche Verwaltung - Polizeimanagement” (Közigazgatás-rendőrségi menedzsment), (Public Administration - Police management), feljogosítja a hallgatót a rendőrtanácsos (Polizeirat) első főtiszti rendfokozat viselésére.

$\mathrm{Az}$ intézményt akkreditálták doktori PhD-képzés végzésére. Fokozat szerezhető az alábbi területeken:

- jogtudományok;

- társadalomtudományok;

- állam- és gazdaságtudományok;

- közigazgatás tudományok.

2011-2019. években 19 fő fejezte be a tudományos képzést.

Az egyetem az országos rendészeti/rendőri kutatás és felső szintű továbbképzések egyik németországi alapbázisa.

\section{Az osztrák rendőr felsőoktatás}

A 8,9 millió lakosú Osztrák Köztársaság szintén szövetségi állam berendezkedéssel és ennek megfelelően Szövetségi Rendőrséggel rendelkezik. A rendőrség a legnagyobb szervezetű őrtestület az országban, közel 23 ezer fő munkatársat foglalkoztat 1000 szolgálati helyen. A rendőrtisztképzés alapelgondolása lényegesen különbözik a német és a magyar rendszertől, amennyiben csak levelező felkészítés van, és a rendőrségtől kizárólag a hivatásos tiszthelyettes állomány tagjai pályázhatnak BA-tisztképzésre. A rendőrséghez a tartományi rendőr-igazgatóságokon lehet jelentkezni. A felvettek 24 hónapos alapkiképzést követően az úgynevezett E2b foglalkoztatási csoportba kerülnek tiszthelyettesként.

A magasabb, még mindig tiszthelyettesi E2a csoportba jutáshoz szükséges egy 8 hónapos levelező felkészítés elvégzése. A felvétel feltételei:

- E2b végzettség és kinevezés ebbe az állománykategóriába,

- legalább három év gyakorlati tapasztalat,

- E2a kiválasztási teszt teljesítése.

Lényegében ez az állomány jelentkezhet tisztképzésre. 
A rendőrtiszthelyettes-állomány két foglalkoztatási csoportba tartozik, E2b (2015-ben 15667 fő, a rendőrségi állomány 58\%-a) és az E2a csoport (2015-ben 9185 fő, a rendőrségi állomány 33\%-a). A tiszti állomány, akik a BA-felkészítést követően lehetnek tisztek, az E1 állománycsoportba tartoznak, 2015-ben 607 fő, a rendőrségi állomány 2\%-a. Megnevezésük vezető hivatalnok, és a városi, valamint a kerületi rendőr parancsnoki beosztásoktól felfelé töltenek be pozíciókat. Ezek szerint Ausztriában rendkívül kevés az állomány összlétszámához viszonyítva a rendőrtiszt, és a képzéshez évente igen kevés helyet hirdetnek meg.

A tisztképzés a Wiener Neustadt Gazdasági és Műszaki Szakfőiskolán (alapítva 1994-ben) folyik. A szak a belügyminisztériummal és a védelmi minisztériummal együttmüködésben múködik, a főiskolának a belügyminisztériummal együttműködési szerződése van. Az iskolában öt fakultás található, gazdasági, egészségügyi, műszaki, sport és biztonsági. A tisztképzés 2006 óta folyik a biztonsági fakultás BAés MA-szakjain.

A Wiener Neustadt Szakfőiskolára „Rendőri vezetés” BA-szakra, 25 helyet hirdettek februári jelentkezési és szeptemberi kezdési határidővel. A főiskola honlapján található a felhívás. Az itt szerezhető végzettség angol nyelvű megnevezése: Bachelor of Arts in Police Leadership BA (rendőri vezető alapképzési szakos bölcsész diploma). Hatszemeszteres, 180 kreditet biztosító, levelező képzés. A tananyagot blokkosított formában havonta két hét összevonással dolgozzák fel. A képzés nyelve német, „részben angol”, megjegyzés szerepel a pályázati anyagban. A költség szemeszterenként 400 euró. A tantárgyak a rendőri szakra jellemzőek, szokványosak, nincs szakirányjellegű megosztás. Kiemelhető az angol oktatásnál prezentáció készítése, stratégia bemutatása, konferencián szereplés. Azoknak a hallgatóknak, akik az E2a magasabb tiszthelyettes-felkészítést elvégezték, elismerik az első félévet, rövidül a tanulmányi idejük.

A felkészítés szakmai gyakorlati részét rendőrségi intézményeknél, valamint részben egész Európában, külföldön biztosítják.

A szakra civil személyek is jelentkezhetnek, javasolják a magánbiztonsági cégek vezetőinek, menedzsereinek a tanulmányokat.

Kik részére javasolják/ajánlják a képzést:

- a belügyminisztérium alárendeltségében müködő szervezetek dolgozói az E1 állománycsoportban;

- azon vezető állomány részére, akik magánbiztonsági cégeknél, a magánbiztonsági tanácsadásban és a magán detektívszervezeteknél tevékenykednek;

- a nemzetközi szervezeteknél rendőrségi vonatkozású tevékenységet végző vezetői beosztást ellátó személyek részére;

- az ASFINAG (teljes neve németül Autobahnen- und Schnellstraßen-Finanzierungs-Aktiengesellschaft) egy állami autópálya-üzemeltető cég Ausztriában, vezető beosztású munkatársai részére.

A BA-képzésre pályázó rendőrök esetében a felvételi vizsga három területet ellenőriz: 
- szakmai, jogi ismeretek szintje;

- sportteszt;

- assessment center (értékelési központ, AC), az új munkatársak kiválasztása során alkalmazott módszer, amelynek célja, hogy a kiválasztandó jelöltek várható beválását felmérjék.

A főiskolán található egy „Stratégiai biztonsági menedzsment” masterképzés, amely Master of Arts in Security Management (MA) megnevezésű diplomát kínál. A felkészítés célja csúcsvezetőket adni a teljes biztonsági terület (állami és magán) számára. Az oktatás 120 kredites, négyszemeszteres, évente 20 helyet hirdetnek meg. A végzettek a bel- és a védelmi minisztériumnál, a katasztrófavédelemnél és a magánbiztonsági szférában helyezkedhetnek el.

A bekerülés feltételei:

- szakirányú bachelordiploma, vagy ezzel egyenértékű végzettség lényegében bármely területről (mérnök, gazdasági, rendészeti, természettudományi, kulturális stb.);

- legalább öt év gyakorlati tevékenység biztonsági területen (rendőrség, katonaság, igazságügy, magánbiztonsági vállalkozás, polgári és katasztrófavédelem);

- általános előfeltétel a német nyelv C1 szintű birtoklása.

A felvételi két részből áll, amelyeket egyazon napon szükséges teljesíteni, egy írásos tudásteszt és egy szituatív interjú.

A biztonsági fakultáshoz az itt említett BA- és MA-szak tartozik, valamint a rendőrség részére tanfolyamokat tartanak.

\section{A finn rendör felsőoktatás}

A finn rendőrség első képzési intézményét 1918-ban az ország függetlenné válásakor alapították. A későbbiekben a tisztképzés, még nem mint főiskolai felkészítés, a rendőr alapképzéstől különválasztva, rendőr intézet megnevezésű szervezetben zajlott. 1998-ban a teljes finn felsőoktatást átszervezték. Ekkor hozták létre ebből az intézetből a rendőr szakfőiskolát, és kaptak a résztvevők hallgatói státuszt. 2008 óta a rendőr alap- (tiszthelyettes) és a főiskolai képzés lényegében egy épületben, de két különböző intézményben, Tampere városban folyik. Természetesen a közös elhelyezésre csupán az alacsony létszám miatt nyílik lehetőség.

A felkészítési rendszer néhány ponton lényegesen különbözik a magyarétól.

A Finn Rendőr Szakfőiskola 90 fő munkatárssal tevékenykedik, akiknek körülbelül fele az oktatásban, másik fele a rendészeti kutatásban dolgozik.

A főiskolára történő felvétel feltételei:

- középiskolai végzettség;

- korábbi felvétel a rendőrség állományába; 
- befejezett rendőri alapkiképzés sikeres vizsgával;

- hároméves szakmai gyakorlat;

- azok a rendőrök, akik már rendelkeznek egy főiskolai diplomával szakmai gyakorlat nélkül jelentkezhetnek.

A tisztképzésre a főiskolára ilyen módon csak hivatásos állományú rendőrök kerülhetnek be. Az iskolán egy rendőri szak múködik, amelyre évente 25 főt vesznek fel. A képzés bolognai típusú, 180 kreditponttal.

A felkészítés sajátossága, hogy a képzés két szakaszra („A” és „B”) tagozódik.

$\mathrm{Az}$ „A” szakasz 126 kreditpontos, háromszemeszteres. A tanulmányok célja a rendőr hivatalok meghatározott beosztásai ellátására történő felkészítés (komisario és rikoskomisario), (felügyelő és bűnügyi felügyelő). Az „A” tanulmányi szakasz befejezését követően a hallgatók visszatérnek szolgálati helyeikre.

A „B” tanulmányi szakasz 54 teljesítményponttal csak azon rendőrök számára nyitott, akik meghatározott vezetői beosztásokat töltenek be. A képzés e része a napi rendőri munka ellátása mellett zajlik, és a befejezésekor letett rendőri parancsnoki vizsga előfeltétele a finn rendőrség legtöbb magasabb vezetői beosztása betöltésének.

Mivel csak hivatásos rendőrök tanulnak a főiskolán, ők folyamatosan kapják az eredeti illetményüket, valamint tanulmányi pótlékot, ingyenes orvosi ellátást, szállást és étkezést.

A rendőrség egyes legmagasabb munkakörei betöltéséhez egyetemi végzettség szükséges. Az egyetemi szintű tanulmányokra a Tampere Egyetem Gazdasági és Közigazgatástudományi Fakultás „Biztonsági Igazgatás” szakon nyílik lehetőség.

\section{A francia rendőr felsőoktatás}

A 68 millió lakosú Francia Köztársaságban a rendőrség három típusra bontható szét: az országos szintű nemzeti rendőrségre (police nationale), a városi (önkormányzati) szintű rendőrségre (police municipale) és az országos szintű nemzeti csendőrségre (gendarmerie nationale). Mindhárom kategória a belügyminisztérium alá tartozik szolgálati kérdésekben, de a csendőrség mint a fegyveres erők része szervezeti kérdésekben a védelmi minisztériumhoz kapcsolódik. A police nationale 149 ezer, a police municipale 24 ezer, a gendarmerie nationale 100 ezer munkatársat foglalkoztat.

\section{A nemzeti rendörség}

Az országos rendőrség három testületre tagolódik, minden testületben több rendfokozat található. 
Legmagasabb szintű a CCD (corps de conception et de direction) felsővezetői testület a következő rendfokozatokkal: commissaire, commissaire divisionnaire, commissaire général.

Következő a CC- (corps de commandement) testület, az alábbi tiszti rendfokozatokkal: lieutenant, capitaine, commandant, commandant divisionnaire.

Harmadik a CEA (corps d'encadrement et d'application), az idetartozó rendfokozatok: gardien de la paix, brigadier, brigadier-chef, major. Ahhoz, hogy valaki itt dolgozzon, már nem kell egy tiszti iskolát elvégeznie.

A legalacsonyabb fokozat az adjoint de sécurité (ADS) és a cadet de la République.

A technikai és tudományos rendőri szakértők további testületekbe tagozódnak, ők szintén valamelyik rendőriskolában tanulnak, de nem tisztek.

A tiszti és az alacsonyabb szintû képzésekre a „devenirpolicier.fr” honlapon lehet jelentkezni.

Alap rendőri felkészítés 12 helyen történik az országban (plusz a tengerentúli területeken még négy helyen).

Tisztképzési feladatokat egyetlen intézmény, az École nationale supérieure de la police (ENSP) lát el az országban két helyen (Saint-Cyr-Au-Mont-d'Or és Cannes-Écluse). A tisztképzés minden év szeptemberében kezdődik.

$\mathrm{Az}$ intézménybe történő bejutásnak két módja lehetséges: külsős polgári életből kezdeményezett felvételi vizsga, belsős felvételi vizsga (belügyminisztérium alá tartozó szerveknél dolgozók, köztisztviselők, katonák számára), illetve VAP (voie d’accès professionnel), már rendfokozattal rendelkező rendőrök.

A tisztképzés két szinten zajlik, a rendőrtiszti (officier de police) és a rendőrfőnöki felkészítés (commissaire de police).

\section{Rendörtisztképzés}

Három rendfokozatot foglal magában: lieutenant de police, capitaine de police, commandant de police.

A képzési idő 16 hónap (10 hónap iskolai oktatás, 6 hónap gyakorlat). Az ösztöndíj: 1370 euró és ingyenes lakhatást biztosítanak. A kezdő fizetés: 2433 euró; a karrier végén megkereshető összeg: 4473 euró; 5 éves szolgálatvállalás szükséges.

Felvételi feltételek:

- külsősként a korhatár 18-35 év, hároméves alapdiploma;

- belsősként a korhatár az annál a testületnél lévő korhatár, ahol a jelentkező el szeretne helyezkedni mínusz 11 év, 4 év már letöltött szolgálati idő;

- VAP, valamilyen rendfokozattal rendelkező rendőrök, minimum két év letöltött szolgálati idő, korhatár 50 éves életkorig.

Fontosabb képzési modulok: múveleti parancsnoksági ismeretek, csapatvezetés, pénzügyi és anyagi erőforrások irányítása. 


\section{Rendörfönöki, vezetői felkészités}

Három rendfokozatot foglal magában: commissaire de police, commissaire divisionnaire de police, commissaire général de police.

A képzési idő 22 hónap (10 hónap alapoktatás, 12 hónap gyakorlati oktatás és gyakorlat). Ösztöndíj: 1443 euró + ingyenes lakhatást biztosítanak; a kezdő fizetés 3164 euró. A karrier végén megkereshető összeg 7826 euró. Hétéves szolgálatvállalás szükséges.

Felvételi feltételek:

- külsősként a korhatár 18-35 év, ötéves mesterdiploma megléte;

- belsősként a korhatár 44 éves életkorig, négy év letöltött szolgálati idő;

- VAP: minimum századosi rangfokozattal rendelkező rendőrök, legalább hét év letöltött szolgálati idő, korhatár 50 év.

Fontosabb képzési modulok: a biztonsági kérdések alapjai (15 hét oktatás +3 hét gyakorlat, majd vizsga), a rendőri technikák elmélyítése (17,5 hét oktatás $+5,5$ hét gyakorlat, majd vizsga), a comissaire de police mesterség alapjai (23 hét oktatás +20 hét gyakorlat, majd vizsga), ezután 2 hónap gyakorlat, majd záróvizsga.

A felvételi háromkörös, a felvételi mód szerint eltérő (külsős, belsős, VAP) változnak a feladatok.

A rendőrfőnöki képzésre jelentkező külsős pályázónak a következő vizsgákat kell letennie:

1. kör: általános műveltségi teszt (5 óra), gyakorlati példa megoldása (4 óra), feleletválasztós teszt (1 óra), jogi és/vagy európai uniós témában fogalmazás írása (3 óra);

2. kör: erőnléti felmérés;

3. kör: pszichológiai teszt (3,5 óra): egyéni szituációs gyakorlat (30 perc felkészülés, 30 perc vizsgázás), csoportos szituációs gyakorlat (35 perc), elbeszélgetés idegen nyelven (német, angol, spanyol vagy olasz; 20 perc felkészülés, 20 perc vizsga), elbeszélgetés a vizsgabizottsággal (35 perc felkészülés, 35 perc vizsga).

2021 szeptemberében 350 helyet hirdetnek meg, ebből 175 külsős hely.

2022 szeptemberében 400 helyet hirdetnek meg, ebből 200 külsős hely.

20-20 fő jelentkezhet előkészítő tanfolyamra.

Bolognai rendszerű képzésre és ECTS-kreditpontokra a rendőrtisztképzés okmányaiban nincs utalás.

A lyoni egyetem jogi karán folyik egy „belső biztonság” mesterképzés, ${ }^{6}$ amelyet az ENSP-vel (rendőrtiszti főiskola) közösen szerveznek, de ez nem tisztképzés.

Minden évben vesznek fel külföldi hallgatókat a rendőrtisztképzésre, a 2017-2018-as évfolyamban ez 15 fő volt. Bár a honlap szerint európai országokból

Mesterképzés a lyoni egyetemen: www.univ-lyon3.fr/master-securite-interieure 
is lehet jelentkezni (köztük Magyarországról is), a 2016-2017-es évfolyamon csak afrikai hallgatók szerepelnek, ez a program inkább a volt gyarmati országoknak szól. ${ }^{7}$

\section{Csendőrtisztképzés}

Míg általában a rendőrök a városban, a csendőrök a falvakban és az elővárosi terekben felelnek a rendért (rendfenntartás, bűnmegelőzés).

A csendőrtisztek képzése a franciaországi Melunben található École des officiers de la Gendarmerie nationale-ban (EOGN) történik. Ahogy a rendőrséghez, a csendőrséghez is külső vagy belső felvételi vizsgával lehet bekerülni. A képzés elvégzésével a diákok csendőrtisztté válnak (officier de gendarmerie). Tiszthelyettesi képzésre az ország öt pontján van lehetőség.

Belsős felvételi feltételek:

- Az egyik változat szerint előfeltétel hat év szolgálat tiszthelyettesként (a korhatár 36 év, és plusz feltétel egy alapszakos diploma). A képzés időtartama négy félév, fizetést kapnak, tisztként a kezdő fizetés 2790 euró, a lakhatást biztosítják. A felvételi eljárás kétkörös, alkalmassági vizsga (általános múveltség [4 órás]; az alábbi három közül az egyik vizsgafeladat [esettanulmány, matematikai feladatok vagy konkrét szakmai eset előadása]; pszichológiai teszt) és felvételi vizsga (elbeszélgetés pszichológussal, a felvételi bizottsággal, szakmai ismeretekkel kapcsolatos vizsga, idegen nyelv, fizikai alkalmassági).

- A másik változat szerint 18 év szolgálat (korhatár: 50 év, minimum 6 év tiszthelyettesi szolgálat, és nem kell diploma). A képzés időtartama 11 hónap. A felvételi kétkörös, alkalmassági vizsga (szakmai ismeretek) és felvételi vizsga (szakmai ismeretek és fizikai alkalmassági [3000 méter futás]).

Külsős felvételi feltételek (polgári életből jelentkezők):

- Egyetemet végzettek (feltétel: mesterdiploma). Képzés időtartama: 4 félév, a két év alatt egyre növekvő fizetést kapnak (1755 euró > 1934 euró > 2026 euró), a kezdő fizetés 2790 euró. A felvételi kétkörös. Alkalmassági (általános múveltség, esettanulmány, jogi vagy gazdasági ismeretek, pszichológiai teszt) és felvételi vizsga (pszichológussal, felvételi bizottsággal elbeszélgetés, védelmi és biztonsági témában vizsgázás, idegen nyelv (angol, német, spanyol vagy olasz), fizikai alkalmasság (50 m gyorsúszás, 50 m sprint, 3000 m futás, húzódzkodás és felülés).

- Mérnökök esetében a korhatár 27 év, feltétel a francia állampolgárság, 5 éves mérnökdiploma vagy valamely más diploma, amelyre a csendőrségnél kereslet

\footnotetext{
Forrás: www.ensp.interieur.gouv.fr/International/Cadres-de-police-etrangers-recrutement-et-formation
} 
van. ${ }^{8}$ A képzés időtartama négy félév, fizetés (1755 euró >1934 euró > 2026 euró), a kezdő fizetés 2790 euró, lakhatást biztosítanak. A felvételi rendje, jelentkezési dosszié kiértékelése, majd elbeszélgetés pszichológussal és a felvételi bizottsággal, fizikai állóképesség (50 m gyorsúszás, 50 m sprint, 3000 m futás, húzódzkodás és felülés).

- Katonai iskolát végzetteknek: francia katonaiskola főhadnagyi rangú végzőseinek a képzési idő 1 év.

- Szerződéses állománykategória részére feltétel a hároméves alapdiploma. A képzési idő 11 hónap; a kezdő fizetés 2000 euró.

A 4 féléves képzés során (6 év szolgálatosok, mesterdiplomával rendelkezők), az 1. félévben a vezetésről tanulnak a hallgatók (katonai és taktikai képzés gyakorlatokkal tarkítva), a 2. félévben múveleti egységek munkájába nyernek bepillantást. Az első évben tehetnek ejtőernyős vagy hegyimentővizsgát.

A második évben csatlakoznak be a képzésbe a katonai iskolát végzett tanulók.

A 3. félévben szakmai képzés folyik, a 4. félévben specializációt választanak a hallgatók (közbiztonság, bűnügy, közlekedésbiztonság, rendfenntartás) és műveletirányítási gyakorlatra mennek.

A képzés végén szerzett diploma 7-es szintű (EU), elnevezése: Dirigeant de services opérationnels et fonctionnels de sécurité (Biztonságmúveleti és -múködési vezető).

A 18 év szolgálattal szerezhető diploma 6-os szintű (EU), elnevezése: Responsable d'unité opérationnelle de la gendarmerie (Csendőri műveletiegység-vezető). A legutolsó jelentkezési időszak 2020. szeptembertől 2021. januárig tartott.

\section{A holland rendör felsőoktatás ${ }^{9}$}

A Holland Rendőrakadémiát (Politieacademie) 1992-ben alapították. 2006-ban nyerte el az oktatási minisztérium által adományozott „alkalmazott tudományok egyeteme” címet, amely Hollandiában ahhoz szükséges, hogy egy intézmény akkreditált bachelor- és mesterképzéseket folytasson, valamint tanszékeket hozhasson létre. 2017 januárjában az akadémia a holland rendőrség szervezeti egységévé vált, ezáltal ez az intézmény lépett elő a toborzás, a kiképzés, valamint a rendőri oktatás és kutatás központjává az országban. A Landelijk Functiegebouw Nederlandse Politie (a holland rendőrség független kormányszó szerve, LFNP) 92 rendőri beosztást tart nyilván, amelyek három csoportba sorolhatók: vezetés, végrehajtás, támogatás és amelyek

2019-ben a következők voltak: adatbázis-kezelés, antropológia, orvosbiológia, orvosi genetika, mikrobiológia, citogenetika, analitikus kémia, szerves kémia, szervetlen kémia, belső ellenőrzés (számvitel), mesterséges intelligencia, robotika, integrált rendszerek, rovartan, matematika, térinformatika, számítógépes adatvédelem és digitális jog, anyagtudományok, gazdaságtudomány és üzletvezetés, kiberbiztonság, fizika, gépészet, toxikológia, digitális jelfeldolgozás.

9 Jelen alpont az alábbi tanulmányban található információkra épül: Jan Heinen - Harry Peeters: Higher police education in the Netherlands. In Rogers Colin - Frevel Bernhard (szerk.): Higher education and police. Palgrave Macmillan, 2018. 223-245. 
betöltéséhez különböző végzettségek szükségesek. A Holland Rendőrakadémia nem csak felsőoktatási szintű képzéseket végez, de a terjedelmi korlátok miatt csak azokkal foglalkozunk. A rendőri felsőoktatásban a Bachelor of Policing (rendőri munka alapképzés) nevü képzés a legfontosabb, amely az alábbi szakterületekre terjed ki:

- készenléti szolgálat (emergency response): erőszakos cselekményekhez, balesetekhez, rendzavaráshoz, antiszociális magatartásokhoz kapcsolódó beavatkozások kezelése, partnerek bevonása az irányítóközpontból kapott információk alapján, kritikus incidensek kezelése, kapacitáskezelés;

- közrendvédelem (law enforcement): rendőri szempontból releváns események kezelése, közlekedésbiztonság, környezeti búncselekmények, magas kockázatú területek feltérképezése, elemzése, priorizálása, különböző illetékességi területek közötti váltás, előzetes és utólagos eligazítás;

- bünügyi nyomozás (criminal investigation): egy átfogó nyomozás végzése és koordinálása, együttműködés más nyomozó szervekkel és az ügyészséggel, helyszíni bünügyi munka;

- intézményközi rendőri munka (intragency policing): hatékony (multikulturális) hálózatok létrehozása állami és civil partnerekkel, a rendőrséggel szembeni társadalmi elvárások figyelembevétele, a társadalmi vívmányok rendészeti stratégiákká formálása.

A Bachelor of Policing című program azért is kulcsfontosságú a holland rendészeti felsőoktatásban, mert ez szükséges a beiratkozáshoz a négy mesterképzés valamelyikére:

- rendőri munka mesterképzés (Master of Science in Policing);

- taktikai rendőri munka a végrehajtásban mesterképzés (Executive Master of Tactical Policing);

- bünügyi nyomozás mesterképzés (Master of Criminal Investigation);

- válságkezelés és közrendvédelem (Master of Crisis and Public Order Management).

A Holland Rendőrakadémia nem rendelkezik doktori iskolával, Hollandiában doktori képzés kifejezetten a rendőri munkára irányulóan nincs, csak a kapcsolódó tudományterületek (kriminológia, büntetőjog stb.) valamelyikén lehet egy civil egyetemen $\mathrm{PhD}$-fokozatot szerezni.

\section{Rendőr felsőoktatás az Egyesült Királyságban}

Az Egyesült Királyságban - ahogy sok más területet érintően is - a rendészeti felsőoktatás esetében külön kell tárgyalni Anglia és Wales, Skócia, valamint Írország helyzetét, de a terjedelmi korlátok miatt ehelyütt csak Angliával és Walesszel foglalkozunk. 2012-ben alapították a belügyminisztérium (home office) szerveként a College 
of Policing nevű szervezetet ${ }^{10}$ annak érdekében, hogy jelentősen fejlesszék a rendőri képzést az országban. A szervezet égisze alatt dolgozták ki a Police Education Qualifications Framework (Rendőri Oktatás Minősítési Keretszabályzat, PEQF) nevű dokumentumot, amely egységesítette a rendőri képzéseket. A PEQF megalkotásának egyik fő célja az volt, hogy a rendészeti szakterületet is egyetemi végzettséghez kötött pályává tegyék, hasonlóan az orvosi és a tanári pályákhoz. ${ }^{11}$ Ennek megfelelően 2020 óta a rendőri hivatás felmenő rendszerben egyetemi végzettséghez kötött foglalkozás Angliában, ami azt jelenti, hogy az első kinevezés előtt a rendőri szervhez a jelentkezőnek meg kell szereznie azt a bachelordiplomát, amely a degree in professional policing practice (hivatásos gyakorlati rendőr diploma) nevet kapta. A diplomát az az egyetem bocsátja ki, amely az adott rendőri szervvel közösen megkapta az ehhez szükséges minősítést a PEQF alapján (egy rendőri szerv több egyetemmel is állhat kapcsolatban, illetve több egyetem is pályázhat konzorciumként a rendőri képzések folytatására). A PEQF az alábbi oktatási programokat foglalja magában, amellyel a fenti végzettséget meg lehet szerzeni:

- Police Constable Degree Apprenticeship (rendőr gyakornoki diploma, PCDA)

- Degree Holder Entry Programme (diplomával rendelkezők belépési programja, DHEP)

- Pre-join Degree in Professional Policing Practice (csatlakozás előtti hivatásos gyakorlati rendőr diploma, PJD).

E három oktatási program valamelyikének teljesítése szükséges ahhoz, hogy valaki megkaphassa az első hivatásos rendőri kinevezését. A brit rendőrségnél kilenc rendfokozat van, amelyek közül a constable a legalacsonyabb, de a bachelordiploma már ahhoz is elvárt. Szükséges megjegyeznünk, hogy néhány rendőri szerv esetében még létezik a hagyományos csatlakozási mód is: a kétéves Initial Police Learning and Development Programme (kezdeti rendőri tanulási és fejlesztési program) elvégzése és az előírt próbaidő eredményes teljesítése után kinevezhető rendőrnek az adott személy felsőoktatási végzettség nélkül is. ${ }^{12}$

A PCDA és a DHEP esetében a rendőri szerv teljes munkaidőre szóló szerződést köt a hallgatóval, aki vállalja, hogy a munkaideje 20\%-ában tanulmányokat folytat a rendőri szerv egyik partneregyetemén. ${ }^{13} \mathrm{~A}$ két program között az időbeli kereteket leszámítva (előbbi három-, míg utóbbi csak kétéves) az a fő különbség, hogy a PCDA esetében a hallgató nem rendelkezik felsőfokú diplomával, míg a DHP-program részvevője már úgy kezdi meg a tanulmányait, hogy rendelkezik egy - bármilyen területen szerzett - diplomával. A hároméves PCDA-programra jelentkezőnek rendel-

\footnotetext{
www.college.police.uk

11 M. Mahruf C. Shohel et al.: Police education in the United Kingdom: Challenges and future directions. In Maigul Nugmanova et al. (szerk.): Education, Human Rights and Peace in Sustainable Development. IntechOpen, 2020.

12 College of Policing: Joining as a new PC. (12 November 2020).

13 College of Policing (2020): i. m.
} 
keznie kell egy 3-as szintű végzettséggel, és a program első napjától kezdve rendőri munkát végez.

A PJD hároméves alapképzés, amely szintén bachelordiplomát ad, és nappali, valamint levelező munkarendben is el lehet végezni. A képzés során évente 120 (összesen tehát 360) kreditet kell megszerezniük a hallgatóknak, azzal, hogy a harmadik tanulmányi évben a kreditek egy részét választható kurzusok teljesítésével szerezhetik meg. A levelező munkarendben tanulóknak arányosabban kevesebb kreditet kell teljesíteniük. A diploma megszerzése ebben az esetben megelőzi a rendőri szervhez jelentkezést, amelynek azt követően öt éven belül meg kell történnie. A képzés teljesítése esetén nem garantált a felvétel a rendőri szervhez. Amennyiben a felvétel megtörténik, egy kétéves próbaidő (mint probationary police constable, azaz próbaidős rendőrtiszt) eredményes teljesítése szükséges még a végleges rendőri kinevezés előtt.

Általános bemeneti követelmények:

- 18. életév betöltése;

- brit állampolgárság, vagy szabad mozgás és tartózkodás jogával rendelkező külföldi állampolgár;

- megfelelő egészségügyi és fizikai állapot ideértve a megfelelő látást;

- büntetlen előélet.

Az egyes rendőri szervek ezeken az általános jelentkezési feltételeken felül még plusz követelményeket is támaszthatnak. Jelenleg 35 egyetem folytat rendőri BA-képzést a PEQF minősítési rendszere alapján. ${ }^{14}$

Az Egyesült Királyságban az egyetemek posztgraduális (MSc-, MA- és doktori) képzéseket is folytatnak a rendészettudomány területén, vagy ahhoz kapcsolódóan; összesen 40 ilyen oktatási program létezik. ${ }^{15} \mathrm{~A}$ mesterszakok közül néhány általános rendőri profilú - például professional policing (hivatásos rendőri munka), international policing (nemzetközi rendészet), policing leadership (rendőri vezetés), contemporary policing (kortárs rendészet) - nagyobb részük azonban valamely speciális rendőri területre (szervezett bűnözés, terrorelhárítás, bűnügyi nyomozás, elemző-értékelő munka) koncentrál. Doktori fokozat szerzésére kifejezetten a rendőri munkához kapcsolódóan csak négy egyetemen öt doktori program keretében van lehetőség:

\footnotetext{
14 Anglia Ruskin University; Bangor University; Birmingham City University; Canterbury Christ Church University; Cardiff Metropolitan University; Coventry University; De Montfort University; Edge Hill University; Lancaster; University with Blackpool \& The Fylde College; Liverpool John Moores University; Newcastle College University Centre; Nottingham Trent University; Sheffield Hallam University; Staffordshire University; Teesside University; University College London; University of Bedfordshire; University of Central Lancashire; University of Chester; University of Cumbria; University of Derby; University of East London; University of Gloucestershire; University of Hull; University of Law; University of Northumbria at Newcastle; University of South Wales; University of Suffolk; University of Sunderland; University of Wales Trinity St David; University of West London; University of Winchester; University of Wolverhampton; Wrexham Glyndwr University; York St. John University. Forrás: www.college.police.uk/career-learning/joining-new-pc/universities-offering-professional-policing-degree

15 Forrás: www.postgrad.com
} 
- University of West London (Nyugat-Londoni Egyetem): „Professional Doctorate in Policing Crime and Society" (hivatásos doktorátus a bűnözést és a társadalmat érintő rendőri munkában);

- Liverpool John Moores University (Liverpooli John Moores Egyetem): Advanced Policing Studies (emelt szintű rendőrségi tanulmányok), illetve Doctor of Policing, Security and Criminal Justice (doktorátus a rendőri munka, a biztonságtudományok és a büntető igazságszolgáltatás területén);

- London Metropolitan University (Londoni Városi Egyetem): Policing, Security and Community Safety (rendőri munka, biztonság és közösségek biztonsága);

- Staffordshire University (Staffordshire Egyetem): Criminal Justice and Forensics (büntető igazságszolgáltatás és kriminalisztika).

Érdekesség, hogy ezek közül a felsőoktatási intézmények közül a London Metropolitan University nem folytat rendőri bachelorképzést.

\section{A román rendör felsőoktatás ${ }^{16}$}

A román rendőr felsőoktatás letéteményese a Bukarestben található Alexander Ioan Cuza akadémia (valójában egyetem). ${ }^{17} \mathrm{Az}$ intézmény névadója az Egyesült Román Fejedelemség első uralkodója, fejedelme, Havasalföld és Moldva perszonálunióban történt egyesítője, a mai román nemzetállam megteremtője.

Az iskolát 1949-ben alapították a rendőrség (militia) képzése céljából. Működése során többször átszervezték, kiegészítették, modernizálták. 1951-1953-ban 7. sz. központi iskola megnevezéssel a belügyminisztérium alárendeltségében tevékenykedett, 1953-ban az állambiztonsági minisztérium, majd 1957-től napjainkig ismét a belügyminisztérium irányítása alá került. 1990-1991-ben felsőfokú tisztképző iskola lett. Múködését a felsőoktatási törvény szabályozza, a képzési minisztérium engedélyével akkreditált bolognai típusú bachelor-, master-, PhD-felkészítéseket, továbbképzéseket és rendészeti jellegű kutatótevékenységeket végez nappali, valamint levelező tagozaton és távoktatás formájában. 1991-től kormányhatározat alapján használják a „rendőr akadémia” megnevezést, továbbra is a belügyminisztérium közvetlen alárendeltségében, saját Szervezeti és Múködési Szabályzat alapján a nemzeti felsőoktatás szerves részeként működve.

Az akadémia felépítése a szokványos európai rendszernek felel meg:

- élén a rektor áll;

- tevékenységét a szenátus segíti;

- két rektorhelyettes és a létesítménygazdálkodási igazgatóság főigazgatója képviselik a fontosabb szakterületeket;

\footnotetext{
A román rendőr felsőoktatásról az adatokat Bandi István az Állambiztonsági Szolgálatok Történeti Levéltára (ÁBTL) tudományos munkatársa, román referense biztosította.

17 A román rendôr akadémia honlapja: www.academiadepolitie.ro
} 
- a fakultások végzik a képzést;

- az iskolán hallgatói képviselet múködik.

Fakultások (karok), intézetek és képzések:

- Közigazgatási és jogtudományok fakultás. 2007-től működik belügyi tisztek és más szakemberek, közigazgatásban dolgozók felkészítését végzi, négyéves, 240 kredites rendszerben, nappali és távoktatásos formában.

- Tűzoltó fakultás. Profilja a mérnökképzés (építészmérnök, gépészmérnök, tűzoltó építészeti mérnök, belső gépészeti képzés). A felkészítés négyéves, 240 kreditpontos.

- Levéltári fakultás, bölcsészképzés, meghatározó feldolgozott területek a múvészetek és humán tudományok, történelem.

- Rendészeti (rendőr) fakultás, levelező és nappali tagozattal, képzéssel a rendőrség és a büntetés-végrehajtás részére. Szakirányok: bűnügyes, szervezett bűnözés elleni, közlekedési, közrendvédelmi, gazdaságvédelmi, adatelemző, korrupcióellenes, különleges müveletek, belső elhárítás, kriminalisztika, büntetés-végrehajtás.

- Határrendőr fakultás, amely a 2015/16-os tanévben kezdte meg működését. A határőrtisztképzés megrendelője és a végzettek alkalmazója a határrendészeti főfelügyelőség, az útlevél-főigazgatóság és a bevándorlási főfelügyelőség. Csak nappali tagozaton folyik oktatás.

- Csendőr fakultás szintén csak nappali felkészítéssel és specializációkkal.

- Mesterképzés 1,5-2 éves időtartamban, 120 kreditponttal zajlik.

- Az egyetemen két doktori iskola működik, a jogi, és 2017. januártól a „Közrendvédelmi és nemzetbiztonsági”, valamint habilitálásra is van lehetőség.

- Az egyetemen tevékenykedik a Belügyi Nemzeti Kollégium (Colegiul National de Afaceri Interne CNAI). A szervezet országos és stratégiai vonatkozásban a belügyminisztérium személyi állománya magasabb szintű állandó képzését biztosítja.

- Az emberi jogok és posztgraduális képzést elősegítő és kutatótanulmányi központ megnevezésű egység az egyetemi felkészítést követő posztgraduális képzést és a szakirányú továbbképzéseket végzi.

- Távoktatási központ.

A rendészeti, csendőr és határőr fakultásokon a bachelorképzés hároméves, 180 kreditpontos. A rendészeti karon a büntetés-végrehajtás részére is folyik tisztképzés. Három alapképzési szak múködik a fakultásokon: hadtudományi, nemzetbiztonsági és közrendtudományi. A tantárgyak a szakmára általánosan jellemzők. 
2018-ban 855 helyet hirdettek meg (650 államilag finanszírozott és 205 önköltséges), 2400 pályázó jelentkezett. Az önköltséges képzésből 100 fő közigazgatási, 100 fő jogi, öt fő levéltári területre esett. Felvettek határrendőrt 40 főt, rendőrt 255 főt, csendőrt 40 főt, büntetés-végrehajtási hallgatót 45 főt. ${ }^{18}$ Sajátosság, hogy a nemzeti kisebbségek számára helyeket tartanak fenn, például a rendészeti fakultás nappali tagozat 305 helyéből roma 8 fő, magyar nemzetiségű 6 fő, egyéb kisebbség 4 fö.

2019-ben 770 helyre hirdettek felvételt, 2913 jelentkező pályázott. A felvettek megoszlása: rendőr 36 fő, határőr 77 fő, csendőr 77 fő, büntetés-végrehajtási 40 fő, tûzoltó 232 fő, a többi fakultást nem számolva.

2020-ban végzettek: rendőr- és büntetés-végrehajtási hallgató 290 fő a nappali és 38 fő a levelező tagozaton, csendőr 55 fő. A határrendőr karról nincs adatunk.

Az iskolára történő felvételit területi központok szervezik a Belügyminisztérium Emberi Erőforrás Management Főigazgatóság alárendeltségében. A rendőrséghez történő felvétel eljárás követelményei írásban és filmen, az interneten megtalálhatók. A fizikai felvételi követelményeket 2020. január 1-jétől megszigorították, de a feladatok rendszere más rendőrségekétől lényegesen nem tér el. A csendőrséghez az elvárt testmagasság 170 centiméter. Különlegesség más országok követelményeihez képest, hogy a jelentkező legyen képes a saját testtömegének megfelelő súlyt a talajról felemelni, illetve egy 60 kg-os bábut tíz méterre elvinni.

$\mathrm{Az}$ írásbeli felvételi tesztek eredményeit kódszámmal teszik ki az internetre. Az írásbeli megírása a felvételi első mozzanata.

A belügyminisztérium alárendeltségében tiszti, tiszthelyettesi és továbbképző intézmények működnek, amelyek az alábbi linken megtekinthetők. ${ }^{19}$

\section{A szlovák rendör felsőoktatás ${ }^{20}$}

A szlovák rendőrtisztképzés intézménye a Pozsonyban található Szlovák Rendőr Akadémia (Akadémia Policajného zboru v Bratislave), valójában egyetem, amelynek alapítási története szorosan kapcsolódik a korábbi Csehszlovák Szocialista Köztársaság (eltekintek a későbbi névváltozásoktól) felbomlásához. 1992. júliusban a szlovák képviselők Pozsonyban nyilatkozatot fogadtak el Szlovákia függetlenségéről. 1993. január 1-jével létrejött a mai állam. Az akadémiát 1992-ben alapították, a képzést október 1-jén kezdte meg. Az első időszak az oktatói állomány és a felkészítési rendszer kiala-

\footnotetext{
1 A 2018-as felvételi eredmények a rendőr akadémián: www.romaniatv.net/rezultate-admitere-academia-de-politie2018-cu-ce-note-s-a-intrat-la-alexandru-ioan-cuza_435229.html

19 A román belügyminisztérium alárendeltségében múködő tanintézetek: www.mai.gov.ro/cariera/institutii-de-invatamant-formare-profesionala

20 Az alfejezet összeállításához az adatokat Forró Réka Dorina, a Nemzeti Közszolgálati Egyetem Rendészettudományi Kar harmadik évfolyamos bünügyi szakirányos hallgatója gyüjtötte.
} 
kításával telt el. A múködés alapja a Szlovák Nemzeti Tanács 370/1992. számú rendelete a Szlovák Köztársaság Rendőr Akadémiájának létrehozásáról.

Az oktatási intézmény élén a rektor áll. A szervezet és a múködés a szokványos nyugat-európai rendszert követi és bolognai típusú akkreditált képzés folyik.

$\mathrm{Az}$ akadémia küldetése, hogy főiskolai és egyetemi képesítéssel rendelkező, szakmailag hozzáértő szakértőket képezzen a rendőrség egységeihez, a Szlovák Köztársaság Belügyminisztériumának munkahelyeihez, valamint más állami és nem állami biztonsági szolgálatokhoz, szervezetekhez és az állami közigazgatás számára. Az intézmény fontos feladatait jelenti a tudományos képzés, a rendészeti kutatás, továbbképzések végzése.

A felkészítés tanszékek rendszerére épül az alábbiak szerint:

Rendészeti Tudományok; Európai Integrált Határrendészeti; Bünügyi; Vizsgálati; Kriminalisztikai és Forenzikus Tudományok; Kriminológia; Büntetőjogi; Közigazgatásjogi; Informatikai és Management; Közigazgatási és Válságkezelés; Köztudományi; Magántudományi; Társadalomtudományi; Nyelvi; Testnevelés és Sport.

Akkreditált tanulmányi programok:

Alapképzés:

- személy- és vagyonvédelem szak (nappali);

- biztonsági szolgáltatások a közigazgatásban szak (nappali és levelező).

Mesterképzés:

- személy- és vagyonvédelem szak (nappali és levelező);

- biztonsági szolgáltatások a közigazgatásban szak (nappali és levelező).

Doktori képzés:

- személy- és vagyonvédelem doktori program (nappali és levelező);

- biztonsági szolgáltatások a közigazgatásban doktori program (levelező).

\section{A felvételi rendszer}

Minden programra történő jelentkezés esetén a pályázónak külön pályázatot kell benyújtania elektronikus formában.

A felveendő jelentkezők számát és a tanulmányi felvételre vonatkozó speciális követelményeket a Szlovák Köztársaság Belügyminisztériuma hagyja jóvá a rendőrség és más biztonsági szolgálatok igényeinek megfelelően. A tanulmányra jelentkező felvételét a rendőrség és más biztonsági szolgálatok igényein alapuló személyzeti feladatokat ellátó felettes javasolja. A Szlovák Köztársaság minden állampolgára jelentkezhet, aki teljesítette a feltételeket. A felvételi feltételek az EU tagállamaiból és harmadik országból érkező külföldi jelentkezőkre is vonatkoznak (kiegészítésekkel). 
Nappali bachelorképzésre a polgári életből jelentkezés:

Személy- és vagyonvédelem szakra, rendőrség vagy más állami biztonsági szervezet hallgatójának:

Tanulmányi idő hossza három év. Évente maximális felvehető létszám 100 fő. A jelentkezéshez csatolni szükséges a közalkalmazotti jogviszonyba való felvételre irányuló kérelmet, strukturált önéletrajzot, 49 eurós jelentkezési díjat.

Felvételi vizsga összetevői: fizikai alkalmassági, állami nyelvtudás megfelelő ismeretének ellenőrzése, pszichológiai vizsgálat.

Biztonsági szolgáltatások a közigazgatásban szakra polgári hallgatónak:

Tanulmányi idő hossza három év. Évente maximális felvehető létszám 60 fő. A jelentkezéshez csatolni szükséges: rövid önéletrajz, orvosi alkalmassági igazolás, 39 eurós jelentkezési díj. A felvételi vizsga egy múveltségi teszt. Az EU tagállamaiból és harmadik országokból érkező pályázókra ugyanúgy vonatkoznak a feltételek, mint a Szlovákiából származó pályázókra. Külföldiek abban az esetben vehetők fel, ha bizonyítják a szlovák nyelv ismeretét legalább B2 szinten. Ez a követelmény nem vonatkozik a cseh állampolgárokra és a szlovák nyelvű érettségi vizsgát teljesítő külföldiekre.

Harmadik országokból érkező jelentkezők beiratkozhatnak, előtte azonban szükséges B2-es nyelvvizsgát tenni szlovák nyelvből, valamint rendelkezniük kell ideiglenes tartózkodási engedéllyel vagy állandó lakhellyel. A felvételi vizsga letétele és a szükséges számú pont megszerzése az írásbeli vizsgán történik, a teljes középfokú oktatás tananyagából.

Levelező bachelorfelkészítés:

Személy- és vagyonvédelem szakra kizárólag szlovák állampolgárok, a rendőrség munkatársai és más biztonsági szolgálatok tagjai jelentkezhetnek, legalább hároméves megelőző szolgálattal. A tanulmányok hossza négy év. A felvehető hallgatók száma 80 fő rendőr, 35 fő egyéb biztonsági szolgálattól.

A jelentkezéshez mellékelni szükséges: rövid önéletrajz, érettségi bizonyítvány másolata, igazolás a középiskolát követő rendőri vagy biztonsági képzésről, munkáltató támogató nyilatkozata, 39 eurós jelentkezési dỉj befizetésének igazolása. A felvételi vizsga egy múveltségi teszt.

Biztonsági szolgáltatások a közigazgatásban szakra a polgári életből lehet jelentkezni, külföldiek számára is. A tanulmányok hossza négy év. A felvehető hallgatók száma 60 fő. A felvételi vizsga egy műveltségi teszt. Feltételek, mint a nappali képzésnél.

Mesterképzés:

Nappali kétéves felkészítésre a polgári életből lehet jelentkezni Személy és vagyonvédelem, illetve Biztonsági szolgáltatások a közigazgatásban szakra. Általános ismereti felvételi vizsga van. 
A levelező mesterképzés tanulmányi ideje három év. A jelentkezés feltétele egy főiskolai szintű diploma. A rendőrség állományának tagjai és egyéb biztonsági szolgálatok munkatársai a Személy és vagyonvédelem szakra pályázhatnak. Felvételi vizsga van.

A Biztonsági szolgáltatások a közigazgatásban szakra a polgári életből lehet jelentkezni bármilyen szakos főiskolai diplomával. A felvehető hallgatók száma 60 fő. Felvételi vizsga van.

A rendőr hallgatók a főiskolai képzés idején úgynevezett „kadét” (jelölt) státuszban tanulnak. A kadét közszolgálat célja a rendőri képzettség megszerzése.

A tanulmány során a hallgató jogosult:

- szolgálati fizetésre;

- ugyanarra a felszerelésre, mint a rendőrség tagjai;

- hathetes szabadságra;

- ingyenes szállásra és étkezésre.

Tanulmányai sikeres befejezése után a végzett hallgató leteszi a hivatali esküt, és teljes jogú tagja lesz a rendőrségnek. A végzettek őrmesteri rendfokozatot kapnak.

Rendőr hallgató (kadét) csak az a szlovák állampolgár lehet, aki:

- betöltötte a 18. életévét;

- egészségileg, fizikailag és lelkileg alkalmas a szolgálat ellátására;

- büntetlen előéletû;

- megbízható;

- beszéli az államnyelvet;

- érettségivel rendelkezik;

- állandó lakhelye van Szlovákiában;

- nem tagja politikai pártnak, mozgalomnak;

- cselekvőképes.

A felvételi eljárás kétnapos. Első nap a nyelvi ismeretek ellenőrzése és fizikai felmérés, a második nap a pszichológiai és a múveltségi teszt zajlik. A felvételi rendszer összetevői:

- nemzetinyelv-ismeret, tollbamondás, fogalmazás;

- fizikai felvételi férfiaknak 100 m futás, helyből távolugrás, felülés két perc alatt, felhúzódzkodás, 12 perces futás, úszás 100 m-en, nóknek 50 m futás, két perc felülés, 12 perc futás, 100 m úszás, függeszkedés;

- pszichológia;

- orvosi vizsgálat;

- kifogástalan életvitel ellenőrzése. 


\section{Összegzés}

A vizsgált rendőri képzésekkel kapcsolatban az alábbi tapasztalatok fogalmazhatók meg:

- Az Európai Unióban zajló, minden területre kiterjedő (jogintézmények, ügyészség, vám, közigazgatás, polgári felsőoktatás) egységesülési folyamat jelentős hatást gyakorolt a rendőrségek múködésére, az azokkal szemben támasztott követelményekre, illetve a rendőri felsőoktatás teljes rendszerére. Meghatározóvá vált a bolognai típusú, több lépcsőben zajló (bachelor-, master-) felkészítés. A folyamat csúcsát a doktori iskolák alapítása jelenti, amelyek rendészeti jellegű PhD-képzést tesznek lehetővé. 2005-2015 között a rendészettudomány ezekben az országokban tudományági besorolást kapott, és lehetővé vált a rendészet tárgyának magasabb szintű intézményi vizsgálata.

- A rendészeti, rendőri ismeretek összetevői lényegében minden tanulmányozott országban azonosak, az oktatott tantárgyak belső tartalma és a feldolgozás módszerei jelentős hasonlóságot mutatnak. A moduláris felépítés, a kreditpontos értékelés és a kapcsolódás az Erasmus-program változataihoz megkönnyítik a hallgatók tanulmányi és szakmai gyakorlatokon történő cseréjét, illetve polgári főiskolákon rendészeti, jogi profilú tantárgyak felvételét.

- A toborzás és a felvételi rendszerek nagyfokú hasonlóságot mutatnak. A bekerülési követelmények szinte azonosak. Eltérés a külföldi, európai uniós, valamint az unión kívüli jelentkezők befogadása területén tapasztalható. A magyar rendszer a legszigorúbbak közé tartozik. Kivételesen egyes tanintézetek lehetővé teszik középiskolai végzettség nélkül a felvételt különböző „rásegítő, támogató” megoldások alkalmazásával. Nemzetiségi, például roma bekerülési keretek léteznek Romániában. Egyes iskolák, illetve rendőrségek (Hamburg) figyelemre méltó aktivitást és megoldásokat alkalmaznak a középiskolások körében toborzás céljából.

- A magyar felvételi rendszer más országokhoz képest rendkívül szorosan kapcsolódik a polgári felsőoktatási szisztémához. A rendőrségek a vizsgált országokban a mienknél lényegesen nagyobb mozgástérrel rendelkeznek a kiválasztás terén, kevésbé veszik figyelembe a középiskolai tanulmányi eredményeket, és a felvételi eljárás során jelentősebb mozgásterük van saját követelményeik érvényesítésében.

- Meghatározó eltérések mutatkoznak abban a kérdésben, hogy a középiskolákból, illetve a rendőrtiszthelyettes-állományból milyen arányban vesznek fel hallgatókat. A csak a tiszthelyettesek jelentkezhetnek (Ausztria) 75\%, tiszthelyettes (Bajorország), a többség középiskolás megoldások léteznek. A kétfajta kategória közös oktatása, vagy néhány szemeszteren keresztül történő szétválasztása, majd együttes képzése is a változatok közé tartozik. Levelező tisztképzés nincs, vagy csak levelező tisztképzés van szélsőségek is tapasztalhatók. 
- A képzés nem olyan széleskörűen bomlik szakirányokra, mint hazánkban. Általában csak két szak (búnügyi, közbiztonsági), vagy csak egy szak, amelyen belül 3-4 modul képez bűnügyi, illetve közbiztonsági hallgatókat. A Magyarországon alkalmazott rendkívül hosszú vizsgaidőszakok sincsenek a tanulmányi programokban, ezzel a megoldással több száz kontaktórával több található a felkészítésben.

- A tudományos fokozatok megszerzése a rendőri területen még nem általánosan jellemző Európában, a rendkívül fejlett Egyesült Királyságban is csak öt doktori program létezik, Hollandiában pedig nincs is ilyen. Sokkal gyakoribb, hogy a rendőri végzettséggel rendelkezőknek csak egy másik tudományterületen (például jogtudományok, közigazgatás-tudományok, biztonságtudományok) van lehetőségük PhD-fokozatot szerezni. Ennek fényében különösen nagy eredmény, hogy hazánkban 2016 óta múködik a Rendészettudományi Doktori Iskola.

\section{FELHASZNÁLT IRODALOM}

College of Policing: Joining as a new PC. (12 November 2020). Online: www.college.police.uk/career-learning/joining-police/joining-new-pc

C. Shohel, M. Mahruf - Gias Uddin - Julian Parker-McLeod - Daniel Silverstone: Police Education in the United Kingdom: Challenges and Future Directions. In Maigul Nugmanova et al. (szerk.): Education, human rights and peace in sustainable development. IntechOpen, 2020. Online: https://doi.org/10.5772/intechopen.92705

Fórizs Sándor: Gondolatok Németország rendőrségi rendszeréről. Belügyi Szemle, (2015), 10. 4764. Online: https://doi.org/10.38146/BSZ.2015.10.4

Heimo, Mikkola - Alexander Rozanov - Valentina Komleva (szerk.): Education, human rights and peace in sustainable development. IntechOpen, 2020. Online: https://doi.org/10.5772/intechopen.92705

Heinen, Jan - Harry Peeters: Higher Police Education in the Netherlands. In Rogers Colin - Frevel Bernhard (szerk.): Higher education and police. Palgrave Macmillan, 2018. 223-245. Online: https://doi.org/10.1007/978-3-319-58386-0_11

\section{ABSTRACT}

\section{Police Education in Several Member States of the European Union, Good Practices Sándor FÓRIZS - Bence MÉSZÁROS}

The higher education in the field of law enforcement started in Hungary 50 years ago. Since then, the education made significant progress at the Faculty of Law Enforcement of the University of Public Service, the legal successor of the Hungarian Police College. From the establishment of several master programs (amongst others, law enforcement leadership management master program, criminalistics master program and security management master program for civilians) to the official accreditation of the Police Science Doctoral School, many progressive changes 
were made. On the occasion of the anniversary, the authors examine the characteristics of similar educational programs in the United Kingdom and in several member states of the European Union, and introduce the good practices followed in these states, which can possibly be adopted in Hungary, as well. The reader can get an insight into the national systems of eligibility criteria of the institutes providing police education, into the structural and substantial characteristics of bachelor and master programs and into several affiliated PhD programs. The study introduces the structure of several foreign higher education institutions providing police education, reviews the other possible tasks carried out by these entities, for example the participation in the further development of police officers or the education in the field of private security. The interested reader can get information on models, within the framework of which the police education takes place in a civilian institution. The overview made by the authors evaluates the possible variations of professional administration of police education, the legal status of students participating in it, the main questions of their quartering, training and appointment to commissioned officer.

Keywords: police education abroad, modular courses, eligibility criteria, police university, police college, international good practices 